\title{
Planning for Extracurricular Activities
}

\author{
Hanif Al Kadri \\ Department of Educational Administration \\ Universitas Negeri Padang, Indonesia \\ hanifalkadri@fip.unp.ac.id
}

Tia Ayu Ningrum

Department of Educational Administration

Universitas Negeri Padang, Indonesia

tia.ayu.ningrum92@gmail.com

\author{
Yulianto Santoso \\ Department of Educational Administration \\ Universitas Negeri Padang, Indonesia \\ yuliantosantoso@fip.unp.ac.id \\ Ratnawati \\ Department of Educational Administration \\ Universitas Negeri Padang, Indonesia \\ ratna.wati804@yahoo.com
}

\begin{abstract}
The research was conducted to determine planning extracurricular activities in junior high school. This study is a descriptive study using a quantitative research approach. The study population was all coaches of extracurricular activities, amounting to 55 people, with a sample using the formula Slovin to 39 people. Data were collected by a questionnaire with Likert Scale models that have been tested for validity and reliability. The results of this study show planning extracurricular activities have been planned well. Planning made had planned types of activities, schedules and extracurricular activities infrastructure. Planning constrained extracurricular activities of the funds will be used because of the source of the funds used only from school operational funding (BOS).
\end{abstract}

Keywords: planning, extracurricular, activities

\section{INTRODUCTION}

There are various extracurricular activities that can be carried out in school as mentioned in (Peraturan Pemerintah No 62 Tahun 2014 Mengenai Ekstrakurikuler Pendidikan Dasar dan Menengah, n.d.): Activities, for example: Scouting, Student Leadership Training (LKS), Youth Red Cross (PMR), Business School Health (UKS), Flag Lifting Force (Paskibra), and others, 2) Scientific work, for example: Youth Scientific Activities (KIR), scientific mastery activities and academic abilities, research, and others, 3) Talent training, for example: the development of sports, arts and culture talents, nature enthusiast, journalism, theater, information and communication technology, engineering, and others, 4) Religion, for example: religious studies, Qur'anic writing, short-term Islamic boarding school, retreat, bible study, worship, traditional rites, religion discussion, and other extracurricular activities.

These extracurricular activities require a very mature plan before implemented at school. Planning extracurricular activities in school should be based on the needs, talents, and interests of students. Planning extracurricular activities, in (SMP, 2014) published by the directorate of junior high school development in 2014, includes planning goals, determining the types of extracurricular activities as needed, planning a supervisor as well as his duty for each extracurricular activity, planning the order, planning the schedule and infrastructure to be used in the activity, and planning the budget needed for the implementation of activities.

As the research population, all middle schools in Pariaman city conduct extracurricular activities. However, the monitoring and preliminary data obtained indicate that the planning of extracurricular activities in Pariaman is still poor. The initial conclusion obtained based on monitoring and interview with several school principals and coaches shows that the planning considered not too crucial because the school extracurricular activities are done regularly by schools from year to year. Various phenomena arise related to the poor planning of extracurricular activities in the school. First, types of extracurricular activities planned in some schools have not been varied and they only repeat and continue activities from previous years, such as sports and scouts, and arts. Second, there is no design of clear extracurricular activities that can be used as guidelines for the implementation of types and time of activities, also the one who is responsible for the activity. Thus the implementation tends to be done spontaneously and tries to adjust to the situation

Furthermore, there is almost no special assignment related to the person in charge of extracurricular program activities (coach of each type of extracurricular activity). Thus they only lean on to teachers who accidentally available at that time. Lastly, there is no certainty related to the room used for the activities. Thus the activities are always moving around and the person in charge wastes most of his time just to find the available room for students.

\section{METHOD}

This research is a quantitative descriptive. The population in the study is 55 coaches of extracurricular activities with 39 people using the Slovin formula. The instrument used is a questionnaire distributed directly to 39 people as the research sample.

\section{A. Research Results}

\section{RESULT AND DISCUSSION}

The results of this study will describe the planning of extracurricular activities in all junior high schools in Pariaman city in terms of a) preparation, b) analysis of talent needs and interests of students, c) participants, d) schedule of activities, e) criteria and guidelines for 
implementing activities, f) facilities and infrastructure, g) development of extracurricular activities, and h) budget for activities.

\section{Preparation}

The results showed that aspect of activity preparation is in a good category, with an average score of 4.09 and a performance level of $77 \%$. This shows that all Junior High School in Pariaman city has prepared the planning of extracurricular activities well.

The highest achievement in the aspect of planning activity preparation is the ability of the coach to prepare extracurricular activity plans for each new school year with an average of 4.49 at the $90 \%$ achievement level. While the lowest achievement level is in the involvement of school committees and student representatives (OSIS) in conducting activity planning with an average of 3.31 at the $67 \%$ achievement level.

\section{Analysis of students talent and interest}

The results show that the aspect of the analysis of talent and interest of students are in a good category, with an average score of 4.35 and an achievement rate of $88 \%$. This shows that the coaching of extracurricular activities in all Junior High School in Pariaman city has analyzed the talent needs and interests of students before the extracurricular activities begin. Therefore, children can be categorized based on their talents and interests.

The highest achievement of this aspect is related to the ability of the coach to design the types of extracurricular activities that will be carried out with an average of 4.49 at the $90 \%$ achievement level. While the lowest level of achievement is the ability of coaches in planning the types of extracurricular activities, by innovating/reforming the activities that will be carried out from the previous year with an average score of 4.13 at the achievement level of $83 \%$. This means that until now the type of extracurricular activities tends to only continue the previous years' activities without initiative develop and add more varied activities.

\section{Participant}

The participant aspects of extracurricular activities are in a good category, with an average score of 4.1 and an achievement rate of $83 \%$. This shows that coaching extracurricular activities in all Junior High Schools in Pariaman city has planned participant extracurricular activities well. So that the number of participants in extra activities tends to increase every year.

The highest achievement of this aspect is related to the coachability to plan the method of selecting extracurricular activities followed by students with an average score of 4.28 at the $86 \%$ achievement level. While the lowest level of achievement is in the ability to compile conditions for students to take part in certain extracurricular activities with an average score of 3.97 at the achievement level of $80 \%$. Therefore, standards and special conditions have not yet emerged and met by students if they want to choose extracurricular types or activities. This situation has an impact on the process and results of activities because students may choose and pass the selection to enter the same type of activity.

\section{Schedule of activity}

The results show that this aspect is in a very good category with an average score of 4.61 at the achievement rate of $93 \%$. This indicates that extracurricular activities of all Junior High Schools in Pariaman city have been very well scheduled.

The highest achievement of this aspect is the coachability to arrange the schedule for the implementation of extracurricular activities without disrupting the teaching and learning activities with an average score of 4.69 at the achievement level of $94 \%$. While the lowest achievement is the ability to determine the day and time of implementation of each type of extracurricular activity which is the average score of 4.51 at the achievement level of $91 \%$.

\section{Assessment and guideline in activity implementation}

The aspect of assessment and guideline in activity implementation is in a good category, with an average score of 3.85 and an achievement level of $78 \%$. This shows that all Junior High Schools in Pariaman city have planned well how to assess and guide the implementation of extracurricular activities that they will carry out every semester.

The highest achievement is related to the coachability to arrange the order for each extracurricular activity with an average score of 4.10 at the achievement level of $82 \%$. While the lowest achievement is the coachability to compile the guidebook for each extracurricular activity with an average score of 3.59 at the $72 \%$ achievement level.

\section{Facility and infrastructure}

The results show that the aspects of facilities and infrastructure are in a good category, with an average score of 3.96 and an achievement rate of $80 \%$. This shows that all Junior High Schools in Pariaman city have planned the facilities and infrastructure needed for extracurricular activities well.

The highest achievement of this aspect is the coachability to determine the place and room used for each extracurricular activity with an average score of 4.13 at the achievement level of $83 \%$. While the lowest achievement is related to the coachability to analyze the equipment needed for each extracurricular activity.

\section{Coach of extracurricular activity}

The aspect associated with the development of extracurricular activity is in a good category, with an average score of 4.31 and an achievement rate of $87 \%$. This indicates that all Junior High Schools in Pariaman city have planned well who is responsible for each extracurricular activity in their respective schools.

The highest achievement is that the coaches of extracurricular activities are appointed directly with an average score of 4.33 at the achievement level of $87 \%$. While the lowest achievement is in setting and dividing tasks for each coach of extracurricular activities with an average score of 4.28 at $86 \%$ achievement level.

\section{Budget for activity}

Following the preliminary data obtained, the budget aspect shows a considerable problem for the school in conducting this extracurricular activity because the aspect is in the sufficient category with an average score of 3.11 at the achievement level of $63 \%$. This shows that all Junior High Schools in Pariaman city does experience problems related to the budget, although 
solutions can still be found to make sure the activities run well.

The highest achievement is related to the coachability to prepare the budget for extracurricular activities from school funds with an average score of 4.15 at the achievement level of $83 \%$. The lowest achievement is in the coachability to set the budget for extracurricular activities through school committee funds and parents with an average score of 2 at the achievement level of $40 \%$.

\section{B. Discussion}

Planning is the main function in the management process (Noe, et al. 2017). Good planning will help the activation process to reach the expected goals. Planning becomes the foundation for carrying out activities. Therefore planning must be adjusted to the needs and expectations of all school academics, especially students and parents (Akos \& Galasi, 2004; Dennis, et. al, 2005, Mau, 1997)

The aspects matter in planning school extracurricular activities are as follows: a) preparation, b) Analysis of student's talent and interest, c) participants, d) Schedule of activity, e) Assessment and guideline in activity implementation, f) Facility and infrastructure, g) Coach of extracurricular activity, and $\mathrm{h}$ ) Budget for activity. The data distribution of planning extracurricular activity are displayed in Table 1.

Table 1

Participant Score Data Distribution Frequency Pretest Score

\begin{tabular}{|c|c|c|c|c|}
\hline No & $\begin{array}{c}\text { Sub Indicator } \\
\text { for Planning } \\
\text { Extracurricular } \\
\text { Activity }\end{array}$ & Average & $\begin{array}{c}\% \\
\text { Achievement }\end{array}$ & Category \\
\hline 1 & Preparation & 4,09 & 82 & Good \\
\hline 2 & $\begin{array}{l}\text { Analysis of } \\
\text { students talent } \\
\text { and interest }\end{array}$ & 4,35 & 87 & Good \\
\hline 3 & Participants & 4,10 & 82 & Good \\
\hline 4 & $\begin{array}{l}\text { Schedule of } \\
\text { activity }\end{array}$ & 4,61 & 93 & Good \\
\hline 5 & $\begin{array}{l}\text { Assesment and } \\
\text { guideline in } \\
\text { activity } \\
\text { implementation }\end{array}$ & 3,85 & 77 & Good \\
\hline 6 & $\begin{array}{l}\text { Facility and } \\
\text { infrastructure }\end{array}$ & 3,96 & 80 & Good \\
\hline 7 & $\begin{array}{l}\text { Coach of } \\
\text { extracurricular } \\
\text { activity }\end{array}$ & 4,31 & 87 & Good \\
\hline 8 & $\begin{array}{l}\text { Budget for } \\
\text { activity }\end{array}$ & 3,11 & 63 & Sufficient \\
\hline
\end{tabular}

The results of the study generally indicate that the planning of extracurricular activities in Junior High Schools in Pariaman city is in the good category with an average score of 4.01 and an achievement rate of $81 \%$. This shows that in general, all Junior High Schools in Pariaman city has planned extracurricular activities well.

The results of the study also show that on average the school already has a good schedule related to the implementation of extracurricular activities because the highest average is related to a sufficiently mature activity schedule of 4.61 at the $93 \%$ achievement level. Whereas the problem still existed related to the budget issues as the data shows that the lowest score is the budget aspect with an average score of 3.11 at the achievement level of $63 \%$. The budget planning has not fully involved the school committee and parents in preparing the budget for extracurricular activities. There are still coaches who have not assigned people to manage the extracurricular activities budget from school funds. Also, there is still a lack of collaboration between coaches and school parents to fulfill budgetary needs.

The efforts that can be done by coaches together with schools in dealing with this problem are to develop cooperation between schools, committees, and parents thus the source of the budget is not only limited from the school funds. Collaboration between schools and parents to fulfill the budget can be done by involving parents' representatives/committee leaders in planning extracurricular activities for schools (Talley \& Keedy, 2006). Hence, parents understand the importance of extracurricular activities to be implemented. This effort can make parents get work together for the success of extracurricular activities at school.

The budget for extracurricular activities should also be obtained from school committee funds in collaboration with parents (Shatkin \& Gershberg, 2007). This is following the Regulation of the Minister of National Education Number 39 of 2008 chapter V article 6 paragraph 1 that 87 "funding for student development in schools is charged to the School Revenue and Expenditure Budget (APBS)".

\section{CONCLUSION}

Based on the results and discussion of the research above, it can be concluded that the results of the study show that in general, the planning of extracurricular activities at Junior High Schools in Pariaman city is in a good category with an average score of 4.01 . The biggest problem currently faced by schools is related to the budget.

Based on the description above, the researcher can put forward some suggestions. First, the coach with the school's academics as well as the community and parents should work together in planning programs, activities and various problems faced by the school in carrying out extracurricular activities each year. Second, there is cooperation between schools, parents and committees in raising funds for extracurricular activities thus School Funds is no longer used as a single source for the activity budget. Last, as well as developing and innovating the types of extracurricular activities each semester hence the types of extracurricular activities planned are following the students' talents and interests

\section{REFERENCES}

[1]. Husaini, U. (2010). Manajemen. (B. Aksara, Ed.). Jakarta.

[2]. Peraturan Pemerintah No 62 Tahun 2014 Mengenai Ekstrakurikuler Pendidikan Dasar dan Menengah.

[3]. SMP, D. P. Juknis Penyusunan Program Pengembangan Diri Melalui Kegiatan Ekstrakurikuler di SMP (2014). Jakarta.

[4]. Terry George dan leslie W. Rue. (2012). Dasar-dasar Manajemen. (P. B. Aksara, Ed.). Jakarta. 
[5]. Noe, R.A., Hollenbeck, J.R., Gerhart, B. and Wright, P.M., 2017. Human resource management: Gaining a competitive advantage. New York, NY: McGraw-Hill Education.

[6]. Akos, P. and Galassi, J.P., 2004. Middle and high school transitions as viewed by students, parents, and teachers. Professional School Counseling, pp.212-221.

[7]. Dennis, J.M., Phinney, J.S. and Chuateco, L.I., 2005. The role of motivation, parental support, and peer support in the academic success of ethnic minority first-generation college students. Journal of college student development, 46(3), pp.223-236.
[8]. Mau, W.C., 1997. Parental influences on the high school students' academic achievement: A comparison of Asian immigrants, Asian Americans, and White Americans. Psychology in the Schools, 34(3), pp.267-277.

[9]. Talley, W.K. and Keedy, J.L., 2006. Assessing school council contribution to the enabling conditions for instructional capacity building: An urban district in Kentucky. Education and Urban Society, 38(4), pp.419454.

[10].Shatkin, G. and Gershberg, A.I., 2007. Empowering parents and building communities: The role of schoolbased councils in educational governance and accountability. Urban Education,42(6), pp.582-615. 